\title{
Pengaruh Model Pembelajaran Berbasis Project Based Learning (PjBL) Untuk Meningkatkan Kemampuan Berpikir Kreatif dan Sikap Kooperatif Mahasiswa
}

\author{
Nurfathurrahmah $^{1}$, Mei Indra Jayanti $^{2}$, Ariyansyah $^{3}$ \\ 1,2,3Program Studi Pendidikan Biologi, STKIP Bima. Jalan Piere Tendean Kel. Mande Tel. Fax \\ (0374) 42801, Bima 84191, Indonesia. \\ Email: fatuncampa87@gmail.com
}

\begin{abstract}
Abstrak
Penelitian bertujuan untuk mengetahui pengaruh model pembelajaran berbasis Project Based Learning (PjBL) untuk meningkatkan kemampuan berpikir kreatif dan sikap kooperatif mahasiswa. Metode penelitian Quasi eksperiment, Teknik pengumpulan data untuk kemampuan berpikir kreatif berupa penilaian pada saat post-test dan pre-test, sedangkan pada sikap kooperatif menggunakan lembar observasi penilaian pada saat mengerjakan proyek serta mempresantikan hasil proyek. Hasil penelitian menunjukkan adanya peningkatan kemampuan berpikir kreatif mahasiswa dari pretest ke posttest sebesar $82 \%(N-$ Gain=0,82) dikategorikan tinggi, begitupula sikap kooperatif mahasiswa dikategorikan tinggi. Maka disimpulkan bahwa terdapat pengaruh model pembelajaran berbasis Project Based Learning (PjBL) untuk meningkatkan kemampuan berpikir kreatif dan sikap kooperatif mahasiswa.
\end{abstract}

Kata Kunci: Pembelajaran Berbasis Proyek (PjBL), Kemampuan Berpikir Kreatif, Sikap Kooperatif Mahasiswa

\section{PENDAHULUAN}

Standar nasional pendidikan berisi kerangka tentang apa yang harus diketahui, dilakukan, dan dikuasai oleh peserta didik pada setiap tingkatan. Kerangka ini disajikan dalam bentuk pengembangan penguasaan ilmu-ilmu dasar dengan sistematika keilmuan yang dapat dipertanggungjawabkan secara akademik (Syamsul, 2010). Sejalan dengan pernyataan (Patmanthara, 2016) "perlunya mengupayakan peningkatan kualitas pembelajaran di Perguruan Tinggi”. Hal inilah menjadi alasan bagi peneliti mengapa pentingnya peranan dosen untuk berusaha meningkatkan kualitas pendidikan baik menerapkan kurikulum berstandar KKNI, meningkatkan kualitas tenaga kependidikan, mengembangkan materi serta bahan ajar sesuai perkembangan IPTEK serta penerapan inovasi dalam pembelajaran melalui model, metode serta strategi yang mengarahkan mahasiswa aktif, mendapatkan pengalaman belajar sepanjang hayat, membentuk akhlak mulia, serta menumbuhkan kepercayaan diri sehingga mampu menghadapi tantangan serta bersaing di era globalisasi abad 21. Pencapaian dalam memenangkan persaingan di era global dapat terlaksana melalui proses belajar yang diarahkan terdapat berbagai pengalaman, keterampilan, mengamati, memahami serta nilai-nilai kesusilaan (Nurfathurrahmah, dkk, 2018).

Pengalaman selama mengajar pada program studi Pendidikan Biologi Sekolah 
Tinggi Keguruan dan Ilmu Pendidikan metode pembelajaran sistematik yang (STKIP) Bima pembelajaran yang terlaksana melibatkan pembelajar dalam belajar pada dasarnya sudah menerapkan beberapa pengetahuan dan keterampilan melalui model pembelajaran hanya saja kurang penyusunan inkuiri yang kompleks, maksimal dalam meningkatkan partisipasi pertanyaan otentik serta desain kerja produk. mahasiswa untuk lebih aktif terlibat selama Siwa, dkk (2013) kerja proyek memuat tugasproses pembelajaran, hal ini dianalisis model pembelajaran yang diterapkan sebatas mengharapkan outputnya adalah peningkatan hasil belajar tanpa mengutamakan sejauh mana peranan mahasiswa dalam menempuh proses belajar yang dapat memberikan pengalaman tidak sebatas sebagai pengetahuan belaka, memberikan lebih banyak kesempatan aktif serta mengungkapkan pemikiran kreatif baik dalam bentuk ide-ide baru, karya yang kreatif, peta konsep atau gagasan-gagasan lain dalam pemecahan masalah berdasarkan informasi serta pengetahuan yang mahasiswa miliki.

Berdasarkan kekurangan yang telah diuraikan, maka sangat perlu diupayakan menerapkan model pembelajaran yang dapat menunjang mahasiswa lebih inovatif, berpikir kreatif serta memiliki sikap kooperatif (saling membantu satu sama lainnya dalam tim). Model pembelajaran yang dapat diterapkan adalah model pembelajaran berbasis Project Based Learning (PjBL) atau pembelajaran berbasis proyek.

Buck Institute Education (2002) dalam Wijayanti (2014) mendefinisikan pembelajaran berbasis proyek sebagai suatu tugas yang kompleks berdasarkan kepada pertanyaan dan permasalahan (problem) yang sangat menantang dan menuntut siswa untuk merancang, memecahkan masalah, membuat keputusan, melakukan kegiatan investigasi, serta memberikan kesempatan kepada siswa untuk bekerja secara mandiri.

$$
\text { Menurut (Setiyawati, }
$$

pembelajaran berbasis proyek sebagai metode pembelajaran yang kooperatif dan akomodatif terhadap kemampuan anak menuju proses berpikir yang bebas dan kreatif. Implementasi pembelajaran berbasis proyek adalah keikutsertaan siswa dalam memahami realitas kehidupan dari yang konkret sampai yang abstrak. Realitas kehidupan ini akan menjadi sumber inspirasi dan kreativitas dalam melakukan analisis dan membangun visi kehidupan.

Berpikir kreatif merupakan salah satu output yang diperoleh dari proyek yang dihasilkan, dimana berpikir kreatif adalah penggunaan kemapuan kognitif untuk menciptakan ide-ide baru maupun mengembangkan gagasan-gagasan baru yang orisinal sesuai pandangan pemikir (Puspitasari, 
2012) dalam (Yarmalinda, dkk, 2017). Baer (1993) dalam Suryani (2014) mengemukakan, ada 4 indikator berpikir kreatif yaitu: fluence (kemampuan menghasilkan banyak ide); flexibility (kemampuan menghasilkan ide-ide yang bervariasi); originality (kemampuan menghasilkan ide baru atau ide yang sebelumnya tidak ada); elaboration (kemampuan mengembangkan atau menambah ide-ide sehingga dihasilkan ide rinci atau detail).

Dalam pelaksanaan proyek untuk mengembangkan kemampuan berpikir kreatif tentunya membutuhkan banyak ide, gagasan serta motivasi dalam menyelesaikan suatu tugas. Oleh kerena demikian dalam penelitian ini dilaksanakan secara kooperatif, hal ini akan menumbuhkan sikap kooperatif. Sikap kooperatif merupakan salah satu sikap yang menunjukan sikap untuk mau bekerja sama dengan orang lain, saling berbagi, saling membantu satu sama lain dan tidak melakukan pertentangan satu dengan yang lain (Deswika, dkk, 2016). Wibisono (2017) menyatakan proses pembelajaran yang dilakukan tidak hanya berorientasi pada perubahan kapasitas kognitif, melainkan juga kapasitas mental secara lebih umum yaitu keterampilan dan sikap yang perlu ditumbuhkembangkan khususnya dalam konteks pembelajaran mahasiswa.
Berdasarkan hasil penelitian

Susilowati, dkk (2013) pembelajaran berbasis proyek berpengaruh terhadap hasil belajar siswa materi system pencernaan manusia. Hasil penelitian Suryani (2014) ada pengaruh penggunaan metode outdoor learning terhadap keterampilan berpikir kreatif mahasiswa ditinjau dari kemampuan akademis awal $(\mathrm{P}=$ 0,000) mahasiswa semester II mata kuliah Morfologi tumbuhan pada program studi pendidikan Biologi STKIP Bima tahun akademik 2013/2014. Hasil penelitian Deswika, dkk (2016) menyatakan ada hubungan yang sangat kuat dan bernilai positif antara penggunaan metode proyek dengan sikap kooperatif anak usia dini. Oleh karena demikian mendukung tujuan penelitian ini untuk mengetahui pengaruh model pembelajaran berbasis Project Based Learning (PjBL) untuk meningkatkan kemampuan berpikir kreatif dan sikap kooperatif mahasiswa.

\section{METODE}

Penelitian ini merupakan penelitian Quasi eksperiment. Dilaksanakan pada semester II program studi pendidikan Biologi STKIP Bima tahun akademik 2018/2019. Sampel 22 mahasiswa. Teknik pengambilan sampel menggunakan sampling jenuh. Instrument pengumpulan data berupa kemampuan berpikir kreatif menggunakan soal 
tes berbentuk essay 5 nomor berdasarkan 4 indikator berpikir kreatif (kelancaran, keluwesan, originalitas, elaborasi) sedangkan sikap kooperatif menggunakan lembar penilaian berupa hasil observasi.

Teknik pengumpulan data untuk kemampuan berpikir kreatif berupa penilaian pada saat post-test dan pre-test, sedangkan pada sikap kooperatif melakukan penilaian pada saat mengerjakan proyek serta mempresantikan hasil proyek.

Teknik analisis data yang digunakan untuk kemampuan berpikir kreatif dengan menganalisis nilai post-test dan pre-test kemudian menentukan peningkatan menggunakan atau uji N-Gain. Adapun tabel N-Gain Yarmalinda, dkk, (2017).

Tabel 1 Klasifikasi Nilai N-Gain

\begin{tabular}{ll}
\hline Nilai $G$ & Klasifikasi Nilai $G$ \\
\hline$G>0,70$ & Tinggi \\
$0,30 \leq G \leq 0,70$ & Sedang \\
$G<0,30$ & Rendah \\
\hline
\end{tabular}

\section{Sikap kooperatif dianalisis} mengguanakan analisis kuantitatif deskriptif. Penilaian ini dilakukan berdasarkan skor mulai 0 sampai 5, pada tingkatan bobot 5 sampai 15 sesuai tingkat kesulitan pada aspek yang dinilai kemudian diakumulasi menggunakan rumus: Nilai $=($ bobot $\mathbf{x}$ skor $): \mathbf{5}$.

Kemudian dinyatakan dalam 5 kategori berdasarkan penyesuai dari sumber Nurfathurrahmah, dkk (2018).
Tabel 2 Kategori Sikap Kooperatif

\begin{tabular}{|c|c|}
\hline Rentang Nilai & Kategori \\
\hline $0-34$ & Sangat rendah \\
$35-44$ & Rendah \\
$55-64$ & Sedang \\
$65-84$ & Tinggi \\
$85-100$ & Sangat Tinggi \\
\hline
\end{tabular}

\section{HASIL DAN PEMBAHASAN}

Hasil penelitian menunjukkan adanya peningkatan kemampuan berpikir kreatif mahasiswa dari pretest ke posttest sebesar $82 \%$ $(\mathrm{N}-\mathrm{Gain}=0,82)$ dikategorikan tinggi, terjadinya peningkatan dikarenakan dalam pelaksanaan pembelajaran berbasis Project Based Learning (PjBL) mahasiswa memdapatkan lebih banyak kesempatan dalam mengembangkan, mengasah serta mengeksplor pengetahuan yang dimiliki berdasarkan pengalaman serta informasi yang pernah dialami, ditemui dalam kehidupan nyata dalam proses pemecahan masalah. Hal ini ditunjukkan pula dari ke empat indikator kemampuan berpikir kreatif dilihat dari nilai pretest dan posttest meningkat yaitu indikator kelancara 43 meningkat 72; keluwesan 44 meningkat 67; keaslian 33 meningkat 67; merinci 32 meningkat 68 . Pencapaian ini sejalan dengan pendapat Sabandar (2008), berpikir kreatif adalah suatu kemampuan berpikir berawal dari adanya kepekaan terhadap situasi yang sedang dihadapi, bahwa situasi itu terlihat atau teridentifikasi adanya masalah yang harus diselesaikan. 
Seiring dengan meningkatnya kemampuan berpikir kreatif mahasiswa, sikap kooperatif mahasiswapun dikategorikan tinggi ditunjukkan dengan jumlah paling banyak mahasiswa yang masuk dalam kategori sikap kooperatif tinggi sebanyak 8 mahasiswa dari jumlah total 22 mahasiswa. Dikarenakan pada proses pemecahan masalah dalam penelitian ini pelaksanaan proyek siswa dapat bertukar pendapat, ide serta bekerjasama dengan teman kelompoknya sehingga memunculkan ide-ide kreatif, pengetahuan serta pengalaman yang baru bagi setiap mahasiswa. Menurut Amanda, dkk (2014) salah satu karakteristik siswa yang dapat mempengaruhi pelaksanaan model pembelajaran berbasis proyek adalah self efficacy (kepercayaan diri), karena siswa dengan self efficacy tinggi akan mengerjakan tugas proyek yang diberikan dengan penuh tanggung jawab, tekun, ulet dan mengerahkan segala usaha serta kemampuannya untuk menyelesaikan tugas tersebut sehingga berdampak pada pencapaian hasil belajar IPA yang optimal.

Hasil penelitian ini sesuai degan hasil penelitian Patmanthara (2016) menyimpulkan implementasi model pembelajaran berbasis proyek dapat meningkatkan aktivitas belajar mahasiswa, dapat meningkatkan hasil belajar aspek pengetahuan, sikap, keterampilan mahasiswa pada matakuliah PBTIK. Jayanti (2018) dalam kesimpulan penelitiannya menyatakan, model pembelajaran berbasis proyek dapat meningkatkan keterampilan berpikir kreatif mahasiswa semester VI kelas C program studi pendidikan biologi STKIP Bima dengan peningkatan gain skor dari rendah menjadi sedang. Penelitian Wibisono (2017) menyatakan melalui pembelajaran kooperatif dinyatakan terjadi peningkatan perilaku bekerjasama antar mahasiswa.

\section{KESIMPULAN}

Maka disimpulkan bahwa terdapat pengaruh model pembelajaran berbasis Project Based Learning (PjBL) untuk meningkatkan kemampuan berpikir kreatif dan sikap kooperatif mahasiswa.

\section{DAFTAR PUSTAKA}

Amanda, N. W. Y., Subagia, I. W., Tika, I. N. (2014). Pengaruh Model pembelajaran Berbasis Proyek Terhadap Hasil Belajar IPA Ditinjau Dari Self efficaty Siswa. eJournal Program Pascasarjana Universitas Pendidikan Ganesha Program Studi IPA, Vol 4, Tahun 2014.

Deswika, E., Sasmiati., Risyak, B. (2016). Penggunaan Metode Proyek Terhadap Sikap Kooperatif Pada Usia Dini. Jurnal. Fakultas kejuruan dan Ilmu Pendidikan Universitas Lampung.

Jayanti, I. M. (2018). Implementasi Model Pembelajaran Berbasis Proyek Untuk Meningkatkan Keterampilan Berpikir Kreatif. Oryza Jurnal Pendidikan Biologi, Vol 7 (2), (1-7).

Nurfathurrahmah., Suryani, E., Ariyansyah. (2018). Peningkatan Keterampilan 
Motorik Mahasiswa Pendidikan Biologi Semester II Melalui Pendekatan Inkuiri Pada Matakuliah Pengelolaan Laboratorium. Prosiding Seminar Nasional Pendidik dan Pengembangan Pendidikan Indonesia (pp 267-270). Mataram, Indonesia: APPPI Wilayah Provinsi NTB.

Patmanthara, S. (2016). Implementasi Model Pembelajaran Berbasis Proyek Untuk Meningkatkan Aktivitas Dan Hasil Belajar Mahasiswa. Tekno, Vol 26 September 2016, (100-107).

Sabandar, J. (2008). Berpikir Reflektif. Makalah. Prodi Pendidikan Matematika Sekolah Pascasarjana UPI.

Setiyawati, I. (2016). Pembelajaran Berbasis Proyek Dengan Memanfaatkan Adobe Flas CS3 Untuk Siswa Sekolah Menengah Kejuruan. Jurnal Apotema, Vol 2 (1), Januari 2016, (41-52).

Siwa, IB., Muderawan, I. W., Tika, I. N. (2013). Pengaruh Pembelajaran Berbasis Proyek Dalam Pembelajaran Kimia Terhadap Keterampilan Proses Sains Ditinjau Dari Gaya Kognitif Siswa. e-Journal Program Pascasarjana Universitas Pendidikan Ganesha Program Studi IPA, Vol 3, 2013, (1-3).

Susilowati, I., Retno, S.I., Sri. S. (2013). Pengaruh Pembelajaran Berbasis Proyek Terhadap Hasil Belajar Siswa Materi Sistem Pencernaan Manusia. Unnes. J. Biol. Educ, 2(1) (2013), (8290).

Yarmalinda, D., Aldina, E. A., Sufi, D. (2017). Penerapan Model Discovery Untuk Meningkatkan Hasil Belajar Kognitif dan Kemampuan Berpikir Kreatif Siswa Pada Pembelajaran Biologi Kelas X MIA 2 SMA Negeri 1 Pabelan Tahun Pelajaran 2016/2017. Prosiding Seminar
Nasional Pendidikan Sains (pp B51B59). Surabaya. Indonesia: PPs Pendidikan Sains Pascasarjana UNESA.

Suryani, E. (2014). Pengaruh Metode Outdoor Learning Terhadap Keterampilan Berpikir Kreatif dan Hasil Belajar Matakuliah Morfologi Tumbuhan Ditinjau dari Kemampuan Akademik Awal Mahasiswa Pada Program Studi Pendidikan Biologi STKIP Bima Tahun Akademik 2013/2014. Thesis. Program Studi Magister Pendidikan IPA Program Pascasarjana Universitas Mataram.

Thalib, B. S. (2010). Psikologi Pendidikan Berbasis Analisis Empiris Aplikatif. Jakarta: Kencana.

Wibisono, S., Gusniarti, U., Nurtjahjo, E. F. (2017). Pembelajaran Kooperatif Sebagai Upaya Meningkatkan Motivasi Empati Dan Perilaku Bekerjasama. SCHEMA-Journal Of Psychological Research, Vol 2 (1), (1-10).

Wijayanti. (2014). Pengembangan Autentic Assesment Berbasis Proyek Dengan Pendekatan Saintifik Untuk Meningkatkan Keterampilan Berpikir Ilmiah Mahasiswa. JPII 3 (2), 102-108. 